\title{
Determination of Susceptibility to Intergranular Corrosion of UNS 31803 Type Duplex Stainless Steel by Electrochemical Reactivation Method: A Comparative Study
}

\author{
Mehmet Emin Arıkan, ${ }^{1}$ Rafet Arıkan, ${ }^{2}$ and Mustafa Doruk ${ }^{1}$ \\ ${ }^{1}$ Metallurgical and Materials Engineering Department, METU, 06800 Çankaya, Ankara, Turkey \\ ${ }^{2}$ Mechanical Engineering Department, Faculty of Engineering, Attlim University, 06836 Incek, Ankara, Turkey \\ Correspondence should be addressed to Rafet Arıkan, rarikan@atilim.edu.tr
}

Received 19 July 2012; Revised 14 September 2012; Accepted 28 September 2012

Academic Editor: W. Ke

Copyright (C) 2012 Mehmet Emin Arkkan et al. This is an open access article distributed under the Creative Commons Attribution License, which permits unrestricted use, distribution, and reproduction in any medium, provided the original work is properly cited.

\begin{abstract}
In the present study as in our previous studies (Arikan and Doruk, 2008 and Arikan et al., 2012), similar specimens taken from a hot rolled cylindrical duplex stainless steel (DSS) bar with $22 \% \mathrm{Cr}$ grade were solution annealed at $1050^{\circ} \mathrm{C}$ and then aged at $800^{\circ} \mathrm{C}$ from 100 to $31622 \mathrm{~min}$ for sensitization treatment. Double loop electrochemical potentiodynamic reactivation and standard weight loss immersion acid tests were conducted. The solution annealed samples were found unsensitized. The samples aged for $100 \mathrm{~min}$ were less sensitized whereas samples aged for $316 \mathrm{~min}$ and more time were sensitized. The degree of sensitization (DOS) can be attributed to higher contribution of chromium and molybdenum depleted areas that result from intermetallic phases. However, especially the samples aged from 3162 to $31622 \mathrm{~min}$ have revealed chromium replenishment. Consequently, the degree of sensitization was lowered in comparison to the results obtained in previous studies.
\end{abstract}

\section{Introduction}

Generally, duplex stainless steels (DSS) are Fe-Cr-Ni alloys having an approximately volumetric fraction of $50 \%$ ferrite and $50 \%$ austenite in their microstructures. Their main feature is that they compromise favorable corrosion resistance of austenitic stainless steels with good mechanical properties [1-4].

However, duplex stainless steels are susceptible to the precipitation of some phases that affect both the corrosion and the mechanical properties. These phases may be formed during the solidification of the alloy or in subsequent heat treatments or plastic deformation processes or even due to ageing processes during its use, causing a marked effect upon the workability and the useful life of the material [5]. One of the possible phases to be formed is the sigma phase $(\sigma)$, a hard and brittle intermetallic compound, rich in $\mathrm{Cr}$ and $\mathrm{Mo}$, which is formed from ferrite [6]. This phase has deleterious effect upon both mechanical and the corrosion properties [7].
In most of the duplex stainless steels sigma phase is formed between $600^{\circ} \mathrm{C}$ and $950^{\circ} \mathrm{C}$ and its precipitation becomes faster between $700^{\circ} \mathrm{C}$ and $900^{\circ} \mathrm{C}$. The embrittlement of some alloys due to the sigma phase precipitation may occur in very short times, of the order of $3 \mathrm{~min}$ [7-9].

Brandi and Padilha [10] and Maehara et al. [11] found the sigma phase precipitation in duplex stainless steels that as the amount of sigma phase increases the amount of ferrite decreases, until its total consumption. According to this result it was concluded that the sigma phase is formed from the ferrite. The proposed mechanism for this formation $[10,11]$ is the eutectoid decomposition of ferrite according to the reaction

$$
\alpha \longrightarrow \gamma_{2}+\sigma,
$$

where $\gamma_{2}$ is the so called secondary austenite. The nucleation rate [12-14] and the kinetics [15] of this reaction have been studied extensively. It is well known that the controlling step is the nucleation rate. The growth of sigma phase 
causes a decrease in chromium and molybdenum content of the neighboring ferrite, which becomes unstable and transforms into austenite. This austenite, in turn, is rich in chromium and molybdenum and has a lower content of nickel if compared with the neighboring ferrite. These changes in chemical composition promote the formation of an additional sigma phase. The overall result is the coprecipitation of secondary austenite and sigma.

Additional phases found in duplex stainless steels can include chi $(\chi)$, laves $(\eta)$, and $\alpha^{\prime}[6]$. The nucleation sites for $\sigma$ and $\chi$ phases are grain boundaries, incoherent twin boundaries, and dislocations.

Duplex stainless steels are susceptible to sensitization due to the precipitation of additional phases when heated in a temperature range of $600-950^{\circ} \mathrm{C}$. These phases have a reverse effect on the corrosion and mechanical properties [16, 17]. A substantial depletion of $\mathrm{Cr}$ and Mo due to a copious precipitation of $\sigma$ and $\chi$ phases results in a decrease of the corrosion properties [18].

The harmful effect of sigma phase has been of great concern in welded duplex stainless steels, because during this heating and cooling process, the sigma phase is formed in the heat affected zones (HAZ) [19-21]. Leaks in pipelines produced with this type of steel were reported to occur in these zones [20].

According to Truman and Pirt [22] this effect is a consequence of $\mathrm{Cr}$ and Mo content decrease in the matrix phase because the sigma phase is considerably richer in these elements than either the ferrite or austenite. Adhe et al. [23] proposed that this decrease is confined to regions adjacent to sigma phase. Wilms et al. [24], on the other hand, observed that the localized corrosion starts next to the sigma phase in the newly formed secondary austenite.

Although the sigma phase has been considered extremely harmful to the corrosion resistance of the DSSs, the available information about it is limited. Thus, it was decided to undertake an investigation of the influence of ageing treatments on the sensitization of the DSS.

There are several test methods for determining the sensitization to intergranular corrosion. Weight loss acid test was first standardized and the test procedure was presented in ASTM A262-91 [25]. Corrosion rate is determined by measuring the weight loss of the sample. Another test method of measuring the susceptibility to intergranular corrosion involves electrochemical reactivation of the steel samples as defined in ASTM G108-94 [26]. This reactivation process is named as electrochemical potentiodynamic reactivation (EPR) and has been developed in single loop (SLEPR) or in double loop (DLEPR) types. The latter was first used for austenitic stainless steels. The best advantage of this technique is that it obtains a quantitative value of the degree of sensitization (DOS) instead of solely qualitative appreciation as metallographic etchings. The EPR test provides the degree of sensitization of the material which is proportional to the amount of chromium depleted areas adjacent to the chromium rich phases.

In this study, DLEPR was applied for the determination of the degree of sensitization of duplex stainless steel type UNS S31803 with 22\% Cr grade. It is designated
TABLE 1: Chemical composition of 2205 DSS (wt.\%).

\begin{tabular}{lccccc}
\hline $\mathrm{C}$ & $\mathrm{Cr}$ & $\mathrm{Ni}$ & $\mathrm{Mo}$ & $\mathrm{Mn}$ & $\mathrm{Fe}$ \\
\hline 0.026 & 22.04 & 4.45 & 2.69 & 1.49 & Ret. \\
\hline
\end{tabular}

by X2CrNiMo 22-5-3 with the trade name SAF2205. The summary of technical literature related to austenitic-ferritic duplex stainless steels shows that test solution for DLEPR often consists of sulfuric acid $\left(\mathrm{H}_{2} \mathrm{SO}_{4}\right)$ solution with the addition of KSCN as depassivator.

The purpose of the present study was to investigate intergranular corrosion behavior of DSS in relation to the influence of the microstructure produced by different heat treatments. This is performed by solution annealing at $1050^{\circ} \mathrm{C}$ and ageing at $800^{\circ} \mathrm{C}$ from 100 to $31622 \mathrm{~min}$ in order to provide different microstructure and sensitization levels. Electrochemical measurements were used to determine the degree of sensitization (DOS) to intergranular corrosion. Light optical microscopy (LOM) was used to identify the different phases that form in bulk material after the heat treatments. X-ray diffraction (XRD) technique and energy dispersive spectroscopy (EDS) analysis were used for studying microstructural evolution. Surfaces obtained after the DLEPR test and the weight loss immersion test were also observed to check the attacked locations and the relationship with the chromium depleted areas.

Similar works were performed by Arikan and Doruk [27] and Arikan et al. [28] on the same type duplex stainless steel aged at $650^{\circ} \mathrm{C}$ and $725^{\circ} \mathrm{C}$, respectively, for various periods of time. The results are compared in Section 3.

\section{Experimental Method}

The same experimental methodology as in our previous studies was applied for the present work. The procedure was given briefly as follows.

The material used was a commercial type hot rolled bar of UNS S31803 duplex stainless steel (DSS) (trade name SAF2205). The chemical composition of the steel is given in Table 1.

The specimens were all solution heat treated at $1050^{\circ} \mathrm{C}$ for 1 hour and then quenched in water, followed by ageing heat treatments at $800^{\circ} \mathrm{C}$ from 100 to 31622 minutes and water quenching.

For metallographic examination, they were etched in $\mathrm{NaOH}$ solution as described in ASTM A923-03 [29]. The solution for etching was prepared by adding $40 \mathrm{~g}$ of reagent grade sodium hydroxide to $100 \mathrm{~g}$ of distilled water. The polished specimens were electrolytically etched at 2 volts for 20 seconds at room temperature. It colors the phases in duplex stainless steel such as austenite in white, ferrite in light brown, sigma in dark brown, and carbides in black.

The weight loss test was done according to ASTM A92303 Test Method C standard. For this, the test solution is prepared by dissolving $100 \mathrm{~g}$ of reagent-grade ferric chloride, $\mathrm{FeCl}_{3}-6 \mathrm{H}_{2} \mathrm{O}$, in $900 \mathrm{~mL}$ of distilled water (approximately 
$6 \% \mathrm{FeCl}_{3}$ by weight). The solution is filtered through glass wool or filter paper to remove insoluble particles. The $\mathrm{pH}$ of the test solution shall be adjusted to approximately 1.3 prior to beginning the test by the addition of $\mathrm{HCl}$ or $\mathrm{NaOH}$, as required.

The corrosion rate is calculated in accordance with the weight loss and total surface area. Unless otherwise specified, the calculated corrosion rate shall not exceed $10 \mathrm{mdd}$. The corrosion rate is calculated in accordance with the following: corrosion rate $(\mathrm{mdd})=$ weight loss $(\mathrm{mg}) /($ specimen area $\left(\mathrm{dm}^{2}\right) \times$ time (days)). Tests are performed using $\mathrm{FeCl}_{3}$ solution with a volume of $20 \mathrm{~mL} / \mathrm{cm}^{2}$ at $25 \pm 1^{\circ} \mathrm{C}$ for 24 hours.

The chemical composition and the profile line analysis of the phases were carried out by EDS with SEM. The presence of different phases was also identified by X-ray diffraction patterns by means of Rigaku diffractometer with $\mathrm{Cu} \mathrm{K}_{\alpha}$ radiation.

DLEPR Tests. The susceptibility of the aged DSS to intergranular corrosion was evaluated using DLEPR test according to ASTM G108 standard [26]. The test was performed according to the recommendations of Majidi and Streicher $[30,31]$. The standard solution is modified to suit duplex stainless steels and consisted of $2 \mathrm{M} \mathrm{H}_{2} \mathrm{SO}_{4}+0.5 \mathrm{M}$ $\mathrm{NaCl}+0.01 \mathrm{M} \mathrm{KSCN}$ at $30 \pm 1^{\circ} \mathrm{C}$ [26]. The test cell consisted of a 1 litre flask with necks for electrodes. A cylindrical working electrode was centrally located and two counter electrodes were placed next to specimen to improve the current distribution. The specimen was mounted according to Stern-Makrides arrangement [26].

The potential was scanned with a rate of $15 \mathrm{~V} /$ hour in the anodic direction from below the $E_{\text {corr }}$ to $+250 \mathrm{mV}$ (SCE) in middle of the passive region and then scanned back to the $E_{\text {corr }}$. The scanning direction was then reversed and hence two loops are generated. The peak activation current $\left(I_{a}\right)$ and the peak reactivation current $\left(I_{r}\right)$ were measured during the forward and backward scans, respectively. The degree of sensitization (DOS) was thus measured as the ratio of the maximum current densities, $\left(I_{r} / I_{a}\right) \times 100[30,31]$.

The activation or critical current density $\left(I_{a}\right)$ or $\left(I_{\text {crit }}\right)$ is proportional to the corrosion rate of a metal. The rate of corrosion rises rapidly in the activation range up to the activation peak current density. The potential corresponding to this is called activation peak potential $E_{a}$ or passivation potential $E_{\text {pass. }}$. If the potential is raised further, the anodic current will drop to a lower value called passivation current density $\left(I_{\text {pass }}\right)$, and then it will remain constant over a wide potential range. This is the passive range in which a thin invisible film of oxide covers the metal surface. This protective film acts as a barrier between the metal and its environment and reduces the rate of dissolution.

During the anodic sweep, the entire surface is active and contributes to the peak current. Nevertheless, during the reactivation sweep, only the sensitized regions contribute to the passive-active transition. The unsensitized specimens show a small $I_{r}$ and result in a small $\left(I_{r} / I_{a}\right)$ ratio. On the other hand, in heavily sensitized specimens, $I_{r}$ approaches $I_{a}$ resulting in a high $\left(I_{r} / I_{a}\right)$ ratio.

\section{Results and Discussion}

3.1. Metallographic Examination. The optical micrographs obtained by etching with $\mathrm{NaOH}$ reagent are given in Figures 1 and 2. Figure 1 represents the microstructure of solution annealed parent alloy in which white phase is austenite $(\gamma)$ and the dark phase is ferrite $(\alpha)$. The volume fractions of $\alpha$ and $\gamma$ were 54 and $46 \%$, respectively. The microstructure does not reveal any visible precipitates of other phases.

To study the influence of the microstructure on degree of sensitization (DOS), the specimens were aged at $800^{\circ} \mathrm{C}$ for times 100, 316, 1000, 3162, 10000, and $31622 \mathrm{~min}$. The ageing heat treatments induced a marked change in the ferrite/austenite ratio caused by the transformation [12], as given by (1). The nucleation rate $[13,32]$ and the growth kinetics of this reaction have been studied extensively [15]. It is well known that the controlling step is the nucleation rate. One of the possible phases to be formed is the sigma phase which is rich in $\mathrm{Cr}$ and Mo.

For specimens aged at $800^{\circ} \mathrm{C}$, microstructural changes are shown in Figures 2(a)-2(f). For ageing $100 \mathrm{~min}$, small precipitates of sigma phase appear at $\alpha / \gamma$ and $\alpha / \alpha$ boundaries. Incoherent twin boundaries and dislocations inside the ferrite matrix may also be the nucleation sites for precipitation [9]. The precipitations of $\sigma$-phase was first encountered after ageing for $100 \mathrm{~min}$ and became more massive with ageing time. Nucleation and growth of $\sigma$ phase are thermally activated processes involving diffusion. Therefore, temperature will have a significant effect on the kinetics of the transformation. After $316 \mathrm{~min}$, a lot of sigma precipitates had developed at $\alpha / \gamma, \alpha / \alpha$ and inside the ferrite phase as shown in Figures 2(b)-2(f). Longer ageing treatment leads to the increase and coarsening of the $\sigma$ phase in an irregular shape.

\subsection{Phase Volume Fraction by Light Optical Microscopy.} Microanalysis reveals that the solution annealed material consists of ferrite and austenite phases. The main microstructural change during ageing is the formation of $\sigma$-phase and secondary austenite $\left(\gamma_{2}\right)$ from the ferrite phase due to the eutectoid reaction (1). The amounts of phases were estimated by measuring the fractions of colored area on polished and etched specimens by light optical microscopy (Leica DMI $5000 \mathrm{M}$ metal microscopy). The measured volume fractions of ferrite, austenite, and sigma phases for different ageing times are given in Table 2 and Figure 3. Since the ferrite transforms into $\sigma$ and $\gamma_{2}$, the ferrite phase disappears in short time (1000 $\mathrm{min})$. The total austenite is considered as the sum of the primary and secondary austenite $\left(\gamma+\gamma_{2}\right)$ and increases to the value of $55 \%$ in $1000 \mathrm{~min}$.

During the early stages of the transformation, sigma forms preferentially at the $\alpha / \gamma$ and $\alpha / \alpha$ grain boundaries and inside the $\alpha$-grain and grows into the ferrite phase via a transformation mechanism involving diffusion. Because both nucleation and diffusional growth of $\sigma$ are thermally activated processes, the ageing time and temperature will have a significant effect on the kinetics of the transformation. The time at which sigma was first observed was $100 \mathrm{~min}$ at $800^{\circ} \mathrm{C}$. 


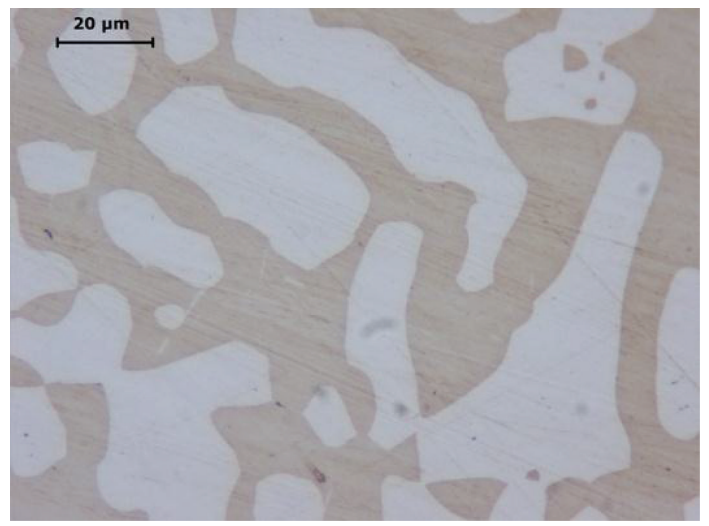

FIGURE 1: Microstructure of DSS, solution annealed at $1050^{\circ} \mathrm{C}$ for 1 hour (austenite in white, ferrite in gray).

TABLE 2: The phase volume percentages obtained from digital image analysis.

\begin{tabular}{lcccc}
\hline Heat treatment & $\begin{array}{c}\text { Ageing time } \\
(\mathrm{min})\end{array}$ & $\begin{array}{c}\text { Ferrite phase } \\
(\text { vol. \%) }\end{array}$ & $\begin{array}{c}\text { Austenite phase }\left(\gamma+\gamma_{2}\right) \\
(\text { vol. \%) }\end{array}$ & $\begin{array}{c}\text { Sigma phase } \\
(\text { vol. \%) }\end{array}$ \\
\hline $\begin{array}{l}\text { Solution annealed at } \\
1050^{\circ} \mathrm{C}, 1 \mathrm{hr}\end{array}$ & 100 & 54.55 & 45.45 & 0 \\
\hline & 316 & 49 & 46.4 & 45 \\
& 1000 & 26.7 & 54.3 & 22 \\
Solution annealed at & 3162 & 1.8 & 55 & 43.7 \\
$1050^{\circ} \mathrm{C}, 1 \mathrm{~h}+$ & 10000 & 0.7 & 55 & 44.3 \\
aged at $800^{\circ} \mathrm{C}$ & 31622 & 0 & 55 & 45 \\
& & 0 & & 45 \\
\hline
\end{tabular}

3.3. Weight Loss Test Results. The susceptibility to intergranular corrosion is given by the loss of weight due to the dissolution of chromium depleted areas and is expressed as the rate of weight loss in $\mathrm{mg}$ per sq. $\mathrm{dm}$ per day (mdd). The results of standard weight loss immersion test are given in Table 3 and plotted in Figure 4. Since the calculated corrosion rate does not exceed $10 \mathrm{mdd}$, the test results are acceptable. The first step of the evaluation of tested specimens was visual and microscopic examination. The degree of sensitization was given by the loss of weight due to the dissolution of chromium depleted areas and is expressed as the rate of weight loss in mdd. The corrosion rate is quite high for $100 \mathrm{~min}$ and increases rapidly up to $1000 \mathrm{~min}$ and then slows down and even a slight decrease is observed for 3162 and $10000 \mathrm{~min}$ of ageing and then increases again slightly by the end of $31622 \mathrm{~min}$. Moreover, the lower chromium and molybdenum content is not the only factor responsible for the increase in the rate of corrosion. The neighborhood of more noble phases (sigma phase) will enhance the anodic dissolution of secondary austenite extensively.

The surfaces of the corroded specimens were examined using LOM. The localized attack in black points is initiated in the secondary austenite phase adjacent to the sigma phase as shown in Figure 5. The austenite and the sigma phases resist the ferric chloride solution more than the ferrite and the secondary austenite. Once a pit is formed it rapidly propagates within the initial ferrite region. As a result, it
TABLE 3: Weight loss immersion acid test results according to ASTM A 923-03.

\begin{tabular}{lc}
\hline Ageing time $(\mathrm{min})$ & Weight loss $(\mathrm{mdd})$ \\
\hline 100 & 2.06075 \\
316 & 4.39316 \\
1000 & 4.99917 \\
3162 & 4.64326 \\
10000 & 4.80819 \\
31622 & 5.09572 \\
\hline
\end{tabular}

is observed that the sigma and austenite phases are almost intact, while the secondary austenite $\left(\gamma_{2}\right)$ and some iron rich ferrite phases are attacked.

3.4. EDS Analysis of Phases. The precipitation of the intermetallic sigma phase is accomplished by the formation of secondary austenite $\left(\gamma_{2}\right)$. As the sigma phase grows, chromium and molybdenum are enriched in these precipitates and, simultaneously, nickel diffuses into the ferrite. The enrichment of $\gamma$-stabilizing elements (such as $\mathrm{Ni}$ ) in the ferrite and the loss of ferrite stabilizing elements (such as $\mathrm{Cr}$ and $\mathrm{Mo}$ ) lead to an unstable ferrite transforming into secondary austenite depleted in chromium and molybdenum [9]. 


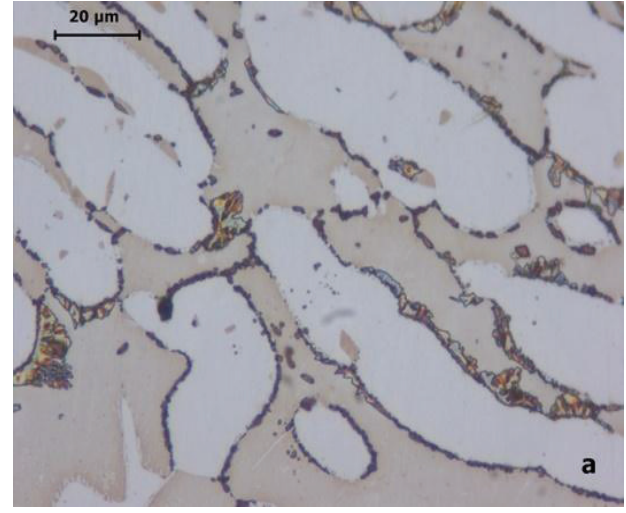

(a)

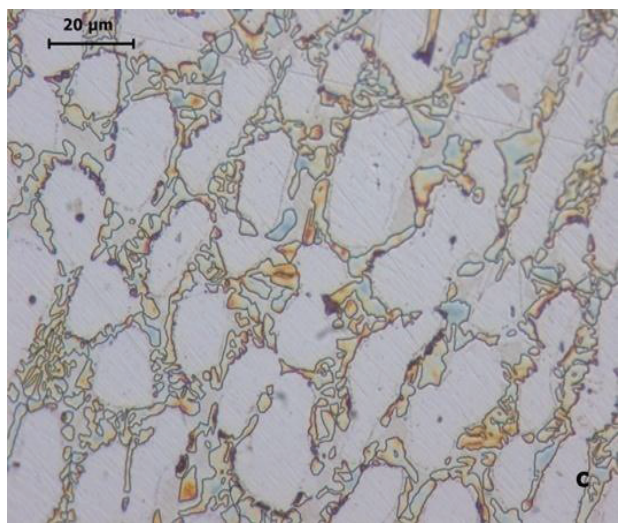

(c)

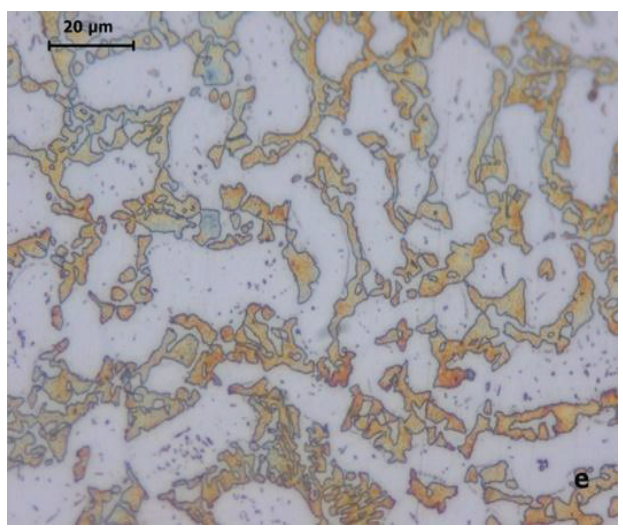

(e)

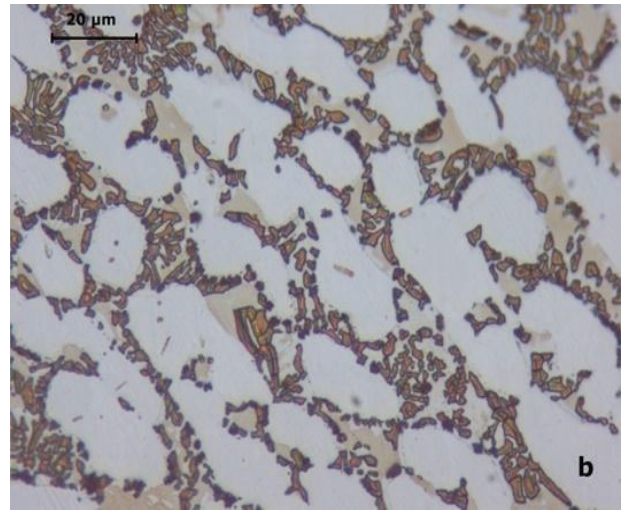

(b)

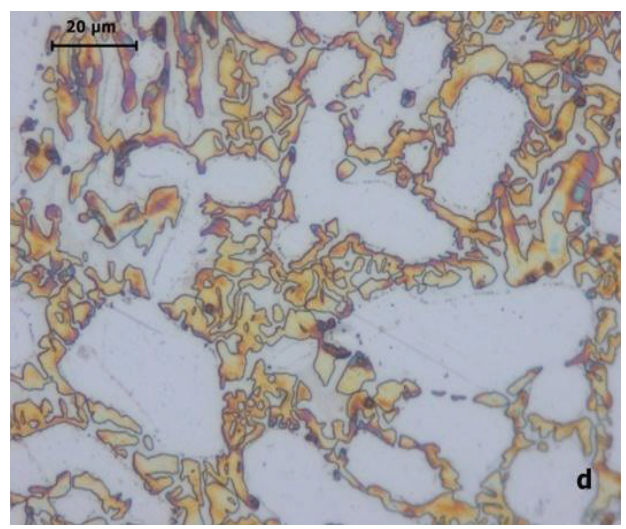

(d)

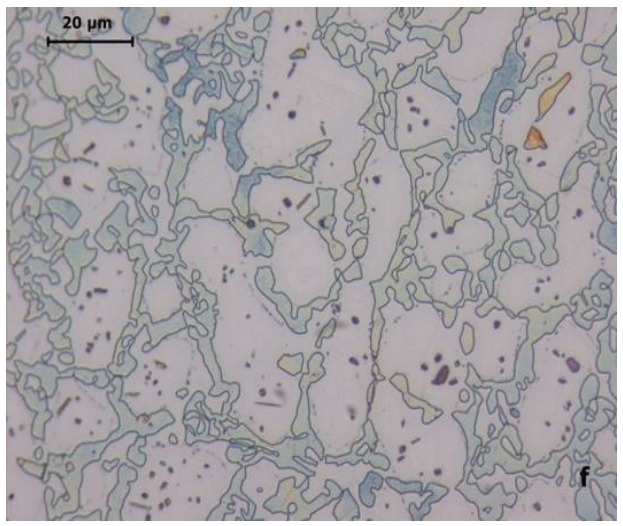

(f)

FIGURE 2: Optical micrographs obtained after ageing at $800^{\circ} \mathrm{C}$ by etching with $\mathrm{NaOH}$ reagent. (a) $100 \mathrm{~min}$, (b) $316 \mathrm{~min}$, (c) $1000 \mathrm{~min}$, (d) $3162 \mathrm{~min}$, (e) $10000 \mathrm{~min}$, (f) $31622 \mathrm{~min}$, (austenite in white, ferrite in gray, sigma precipitates in black).

SEM image and profile line analysis of the sample aged at $800^{\circ} \mathrm{C}$ for $316 \mathrm{~min}$ is given in Figure 6 . The sigma phase appears black, the ferrite dark gray, and the primary austenite light gray. A bright region around the sigma phase is likely secondary austenite. The EDS measurements of $\mathrm{Cr}, \mathrm{Mo}, \mathrm{Ni}$, $\mathrm{Mn}$, and Fe content of the $\alpha, \gamma, \sigma$, and $\gamma_{2}$ phases are given in Table 4 . The relative concentrations of major alloy elements across the secondary precipitates are measured by the line scanning as shown in Figure 6.

The phases have different chemical composition. The results indicate that the $\sigma$ phase was partitioned in $\mathrm{Cr}$ and
Mo where the secondary austenite is depleted in $\mathrm{Cr}$ and Mo. For instance samples aged at $800^{\circ} \mathrm{C}$ for 316 and $31622 \mathrm{~min}$ show depletion of chromium in secondary austenite from $26.32 \%$ to $20.26 \%$ and $20.23 \%$, respectively, and a nearly total loss of molybdenum. Chromium content of the sigma phase reaches to $30.76 \%$ and $35.21 \%$, respectively.

3.5. X-Ray Diffraction Pattern. The results of the X-ray diffraction analysis consist of a series of diffraction patterns given in Figure 7. The diffraction pattern of the solution annealed parent alloy presents ferrite and austenite phase 


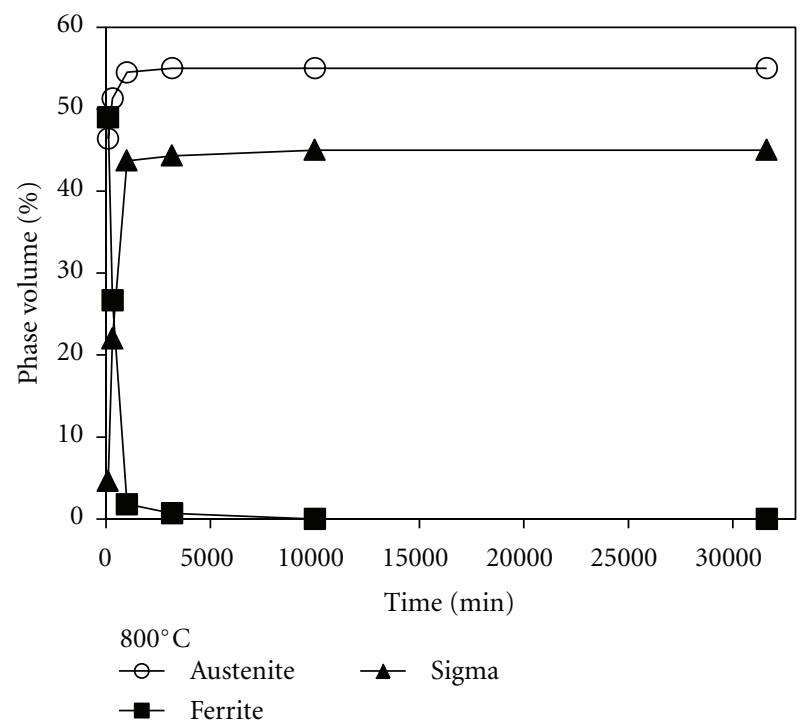

FIgURE 3: Changes in volume $\%$ of austenite, ferrite and sigma phases with ageing time at $800^{\circ} \mathrm{C}$.

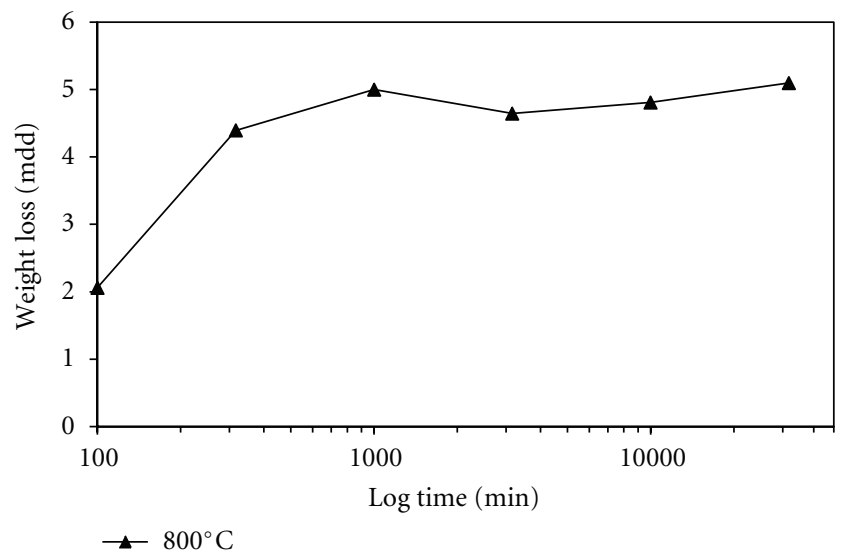

FIGURE 4: The change in weight loss with ageing time.

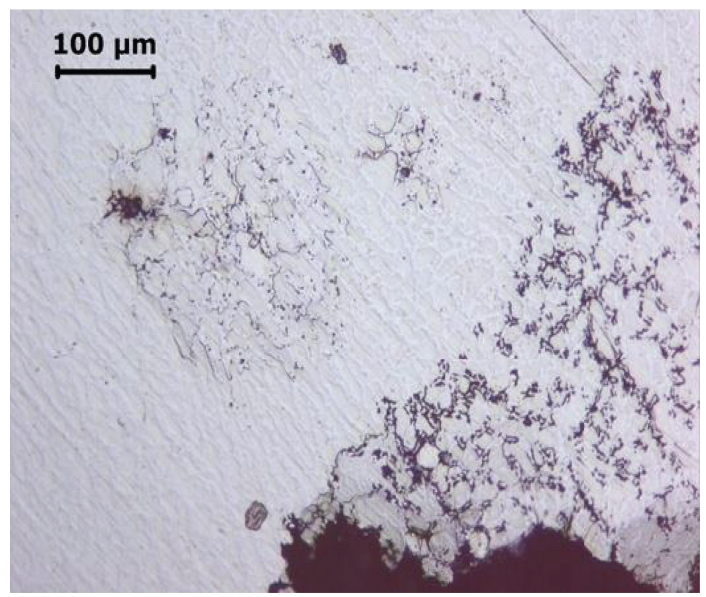

(a)

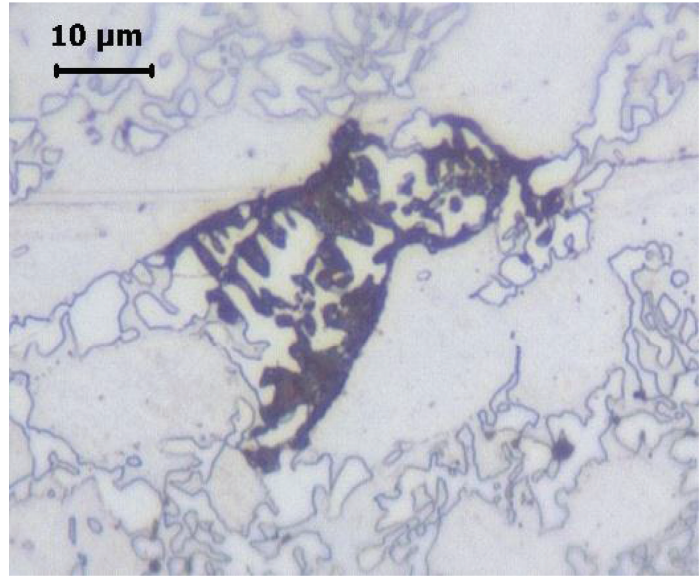

(b)

FIGURE 5: Corroded area of the aged specimen at $800^{\circ} \mathrm{C} / 31622$ min after the standard immersion test for 24 hours. (a) Large initiated areas of localized corrosion (black) and big cavities are formed. (b) The corrosion propagates within the secondary austenite (slightly etched with oxalic acid) adjacent to the sigma phase. 
TABLE 4: EDS analysis of phases present in solution annealed and aged condition of DSS.

\begin{tabular}{|c|c|c|c|c|c|c|c|c|}
\hline Heat treatment & Phase & $\begin{array}{c}\mathrm{Cr} \\
(\mathrm{wt} . \%)\end{array}$ & $\begin{array}{c}\mathrm{Ni} \\
(\mathrm{wt} . \%)\end{array}$ & $\begin{array}{c}\text { Mo } \\
\text { (wt.\%) }\end{array}$ & $\begin{array}{c}\text { Mn } \\
\text { (wt.\%) }\end{array}$ & $\begin{array}{c}\mathrm{Si} \\
(w t . \%)\end{array}$ & $\begin{array}{c}\mathrm{S} \\
(\mathrm{wt} \%)\end{array}$ & $\begin{array}{c}\mathrm{Fe} \\
(\mathrm{wt} \%)\end{array}$ \\
\hline Solution annealed & General composition & 22.04 & 4.45 & 2.69 & 1.49 & 0.45 & 0.003 & 68.29 \\
\hline \multirow{2}{*}{$\begin{array}{l}\text { Solution annealed at } \\
1050^{\circ} \mathrm{C} / 1 \mathrm{hr}\end{array}$} & $\alpha$ & 26.32 & 4.87 & 4.15 & 1.59 & 0.74 & - & 62.32 \\
\hline & $\gamma$ & 23.55 & 7.08 & - & 1.85 & - & 1.19 & 66.33 \\
\hline \multirow{5}{*}{$\begin{array}{l}\text { Aged at } \\
800^{\circ} \mathrm{C} / 31622 \mathrm{~min}\end{array}$} & $\gamma_{2}$ & 22.03 & 6.10 & 2.27 & 2.05 & 0.56 & - & 66.98 \\
\hline & $\gamma_{2}$ & 19.97 & 7.20 & - & 2.22 & 0.72 & - & 69.90 \\
\hline & $\gamma_{2}$ & 20.23 & 6.29 & - & 2.41 & - & - & 71.08 \\
\hline & $\sigma$ & 32.15 & 2.26 & 6.66 & 1.80 & 0.71 & - & 56.41 \\
\hline & $\gamma_{2}$ & 21.92 & 6.16 & - & 1.95 & - & 0.80 & 69.17 \\
\hline \multirow{4}{*}{$\begin{array}{l}\text { Aged at } \\
800^{\circ} \mathrm{C} / 316 \mathrm{~min}\end{array}$} & $\alpha$ & 27.71 & 3.47 & - & - & 0.55 & 0.98 & 67.28 \\
\hline & $\gamma_{2}$ & 26.97 & 2.77 & - & - & - & 0.91 & 69.36 \\
\hline & $\gamma_{2}$ & 20.26 & 4.76 & - & 2.10 & 0.61 & - & 72.28 \\
\hline & $\sigma$ & 30.76 & 3.36 & 7.88 & 1.80 & 0.71 & - & 55.50 \\
\hline
\end{tabular}

TABLE 5: DLEPR test results of 2205 type duplex stainless steel.

\begin{tabular}{|c|c|c|c|c|c|c|c|}
\hline $\begin{array}{l}\text { Temperature } \\
\left({ }^{\circ} \mathrm{C}\right)\end{array}$ & $\begin{array}{l}\text { Time } \\
(\min )\end{array}$ & $\begin{array}{l}\text { Activation peak } \\
\text { potential, } E_{a} \\
(\mathrm{mV})\end{array}$ & $\begin{array}{l}\text { Activation peak } \\
\text { current density, } I_{a} \\
\left(\mathrm{~mA} / \mathrm{cm}^{2}\right)\end{array}$ & $\begin{array}{l}\text { Reactivation peak } \\
\text { potential, } E_{r} \\
(\mathrm{mV})\end{array}$ & $\begin{array}{l}\text { Reactivation peak } \\
\text { current density, } I_{r} \\
\quad\left(\mathrm{~mA} / \mathrm{cm}^{2}\right)\end{array}$ & $\begin{array}{l}\text { Passivation current } \\
\text { density, } I_{\text {pass }} \\
\left(\mathrm{mA} / \mathrm{cm}^{2}\right)\end{array}$ & $\begin{array}{c}\text { DOS } \\
\left(I_{r} / I_{a} \times 100\right)\end{array}$ \\
\hline $\begin{array}{l}\text { Solution } \\
\text { annealed at } \\
1050^{\circ} \mathrm{C}, 1 \mathrm{hr}\end{array}$ & & -212.78 & 23.1304849 & -267.33 & 0.0063918 & 0.001448 & 0.027634 \\
\hline \multirow{6}{*}{$\begin{array}{l}\text { Solution } \\
\text { annealed at } \\
1050^{\circ} \mathrm{C}, 1 \mathrm{hr} \text {, } \\
\text { then aged at } \\
800^{\circ} \mathrm{C}\end{array}$} & 100 & -187.31 & 24.9231381 & -249.84 & 0.4984630 & 0.029998 & 1.9999934 \\
\hline & 316 & -203.12 & 39.2419267 & -238.16 & 6.9135766 & 0.035334 & 17.617832 \\
\hline & 1000 & -179.68 & 44.7944482 & -224.01 & 14.1895596 & 0.038004 & 31.677025 \\
\hline & 3162 & -187.67 & 42.6067788 & -245.27 & 6.58075448 & 0.035494 & 15.680028 \\
\hline & 10000 & -172.55 & 57.9448930 & -197.77 & 35.3551309 & 0.046062 & 61.015094 \\
\hline & 31622 & -145.65 & 69.4685293 & -204.05 & 25.5835941 & 0.040190 & 36.827603 \\
\hline
\end{tabular}

peaks only. Samples aged at $800^{\circ} \mathrm{C}$ for different ageing times show the peaks of phases developed.

Although the precipitations at grain boundaries are evident for $100 \mathrm{~min}$ of ageing as shown in light optical micrograph of Figure 2(a), the X-ray spectra of the sample does not reveal any sigma peak. This may be attributed, as given in Table 2, to the low volume fraction of the sigma phase $(4.6 \%)$.

Samples aged at $800^{\circ} \mathrm{C}$ show sigma peaks first in $316 \mathrm{~min}$ of ageing. With increased holding time, the intensity of sigma peaks increases as the volume fraction of sigma phase increases (Table 2) and also additional sigma peaks appear. After $1000 \mathrm{~min}$ of ageing, one of the ferrite phase peaks decreases to nearly zero but the other peak does not disappear; it overlaps with a sigma phase peak. After longer periods of time such as $10000 \mathrm{~min}$, the treatments promote the transformation of ferrite phase. This results in a noticeable decrease in the intensity of the $\alpha$ and an increase of $\gamma$ peaks. The decrease of the ferrite peak intensity indicates that the major fraction of ferrite is transformed into sigma. Consequently, several sigma peaks are observed. All the changes observed in the diffraction peak intensity correlate well with the changes in volume fraction of each phase during the isothermal hold as given in Table 2.
3.6. DLEPR Results. Figure 7 shows the polarization curves for samples in solution annealed and aged condition. The curve obtained from the solution annealed sample is treated as a reference and compared with the others. The activation peak current density of the reference curve is $23.13 \mathrm{~mA} / \mathrm{cm}^{2}$ and the corresponding activation peak potential $\left(E_{a}\right)$ or passivation potential $\left(E_{\text {pass }}\right)$ is $-212.78 \mathrm{mV}$ with respect to saturated calomel reference electrode (SCE). This peak reaches a maximum and then fall to a low passive current density $\left(I_{\text {pass }}\right)$ of $0.001448 \mathrm{~mA} / \mathrm{cm}^{2}$ before reaching the chosen reverse potential of $+250 \mathrm{mV}$. The sample is thus passivated in a wide range between $-212.78 \mathrm{mV}$ and $+250 \mathrm{mV}$. In this passive range, a thin invisible film of oxide may cover the metal surface. The protective film acts as a barrier between the metal and its environment and reduces its rate of dissolution. And hence, the $I_{r} / I_{a}$ ratio is very low $(0.027634 \%)$. This may be considered as unsensitized material (Table 5).

From the sample aged for $100 \mathrm{~min}$, few sigma phase precipitates were observed optically (Figure 2(a)). The amount is determined by volume fraction which is very small, about $4.6 \%$, (Table 2). Therefore, the diffraction pattern does not reveal any evidence of the phase. Consequently, the sample presents very small reactivation current (Table 5), and hence 


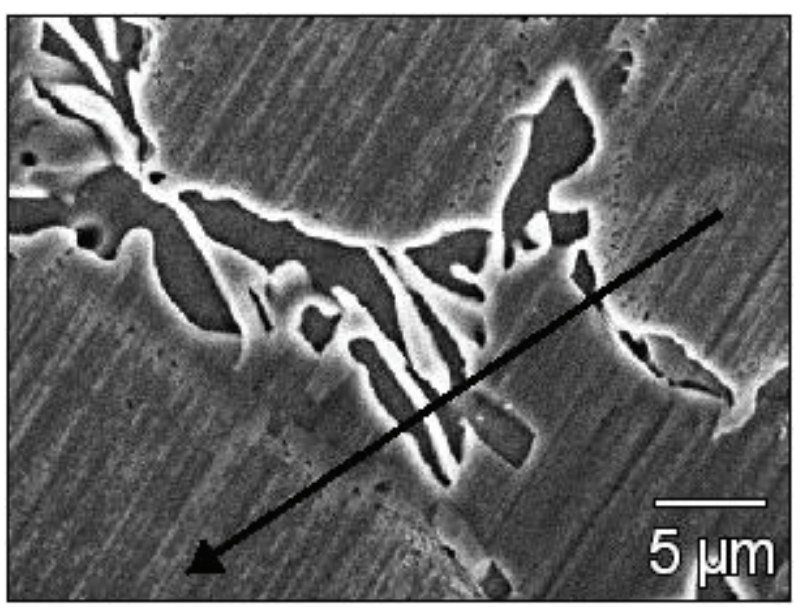

(a)

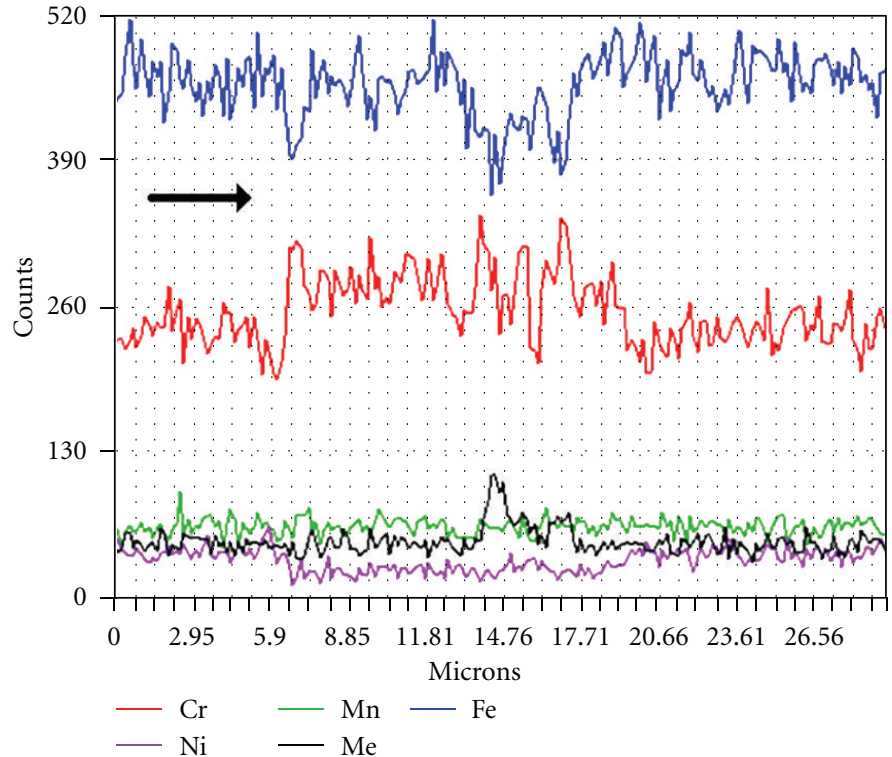

(b)

Figure 6: SEM image and profile line analysis of $\mathrm{Cr}, \mathrm{Ni}, \mathrm{Mo}, \mathrm{Mn}$, and Fe for the sample aged at $800^{\circ} \mathrm{C}$ for 316 min showing chromium depleted areas due to the precipitation of $\sigma$-phase.

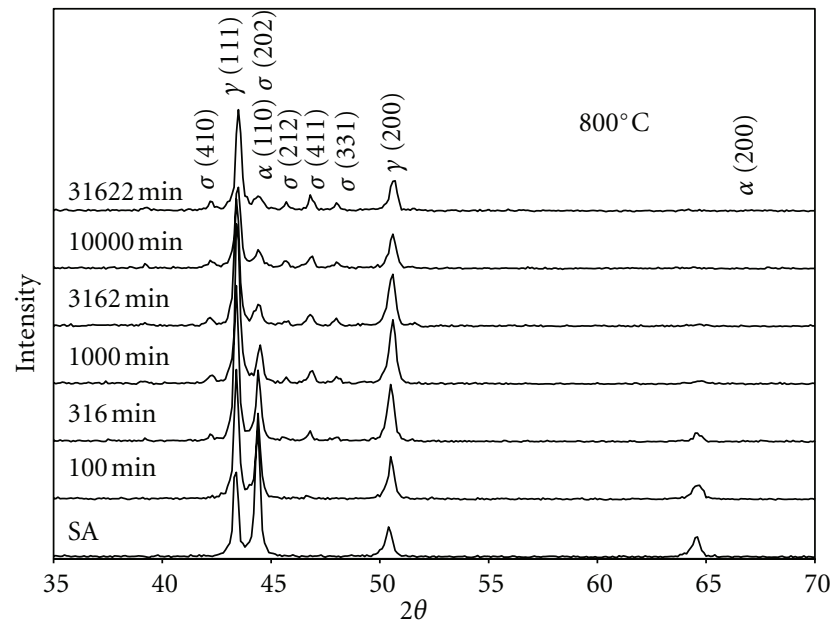

Figure 7: X-Ray diffraction patterns of samples aged at $800^{\circ} \mathrm{C}$.

the $I_{r} / I_{a}$ ratio is $1.99 \%$ and, accordingly, the corrosion rates become $2.06075 \mathrm{mdd}$ (Table 3 ). This means a slight chromium depletion resulting in a less sensitization.

After ageing for $316 \mathrm{~min}$, the formation of a massive sigma phase nucleation at the boundaries and within the ferrite grains was observed (Figure 2(b)). The XRD curves (Figure 7) reveal this evidence because of the significant amount of the phase (22\%) (Table 2). Next to the $\sigma$-phase, the secondary austenite $\left(\gamma_{2}\right)$ forms from the decomposition of ferrite into $\sigma$ and $\gamma_{2}$ (Table 2). Dissolution of the secondary austenite results in greater weight loss $(4.39 \mathrm{mdd})$ (Table 3) and, accordingly, a high ratio of $I_{r} / I_{a}(17.61 \%)$
(Table 5). This means that the sample has been quite sensitized.

The degree of sensitization (DOS) is also given by the loss of weight due to the dissolution of chromium depleted areas. The results are given in Table 3 and plotted in Figure 4. When aged at $800^{\circ} \mathrm{C}$, the corrosion rate is low for $100 \mathrm{~min}$ but increases up to $1000 \mathrm{~min}$ and then slows down and even a slight decrease is observed for 3162 and 10000 min of ageing. Then, it increases again slightly by the end of $31622 \mathrm{~min}$.

The DOS values exhibit a similar trend. For instance, the aged samples mainly for longer ageing treatment such as $1000,3162,10000$, and $31622 \mathrm{~min}$ led to coarsening of the sigma phase and slowed the corrosion rate to $4.99,4.64,4.80$, 
and 5.09 mdd, respectively, and the corresponding current density ratios $\left(I_{r} / I_{a}\right)$ or DOS values are given as $31.67,15.08$, 61.01 , and $36.82 \%$, respectively. These values are lower than those obtained at $725^{\circ} \mathrm{C}$. Higher ageing temperature such as $800^{\circ} \mathrm{C}$ promotes a redistribution of chromium in depleted zones [33]. In other words, it causes the replenishment of the secondary austenite by chromium diffusion from the chromium rich ferrite phase and from the interior of the austenite. As a result, prolonged ageing at $800^{\circ} \mathrm{C}$ causes a decrease in DOS and hence a decrease in corrosion rate in comparing with the results of lower ageing temperatures such as 725 and $625^{\circ} \mathrm{C}$.

When the polarization curves of the samples aged at $800^{\circ} \mathrm{C}$ from 100 to $31622 \mathrm{~min}$ are compared with the reference curve, it is seen that the activation peak current density $\left(I_{a}\right)$ increases with increasing ageing times (Table 5). Also, the passive current density $\left(I_{\text {pass }}\right)$ increases from $0.029998 \mathrm{~mA} / \mathrm{cm}^{2}$ up to $0.040190 \mathrm{~mA} / \mathrm{cm}^{2}$, and the passivation potential $\left(E_{\text {pass }}\right)$ increases from $-212.78 \mathrm{mV}$ to $-145.65 \mathrm{mV}$ (SCE).

From the results discussed so far, considering weight loss acid test and DLEPR test, it can be concluded that both the sensitization and the corrosion rate have increased with respect to the depletion of chromium and molybdenum in the ferrite region.

Chromium diffusion is much faster in ferrite than in austenite. The chromium concentrates in the neighboring sigma phase [34] and causes the sigma phase to grow fast within the ferrite region. As a result, the formation of the secondary austenite can degrade the stability of the passive film [35].

After the DLEPR test, for instance, samples aged for 1000 and $10000 \mathrm{~min}$ were slightly polished and examined with LOM (Figures 9(a) and 10(a)) to check the attack locations and the relationship with the chromium depleted areas. Observation of the surface indicates that the sigma and austenite phases are almost intact, while the secondary austenite and some iron rich ferrite phases are attacked. The corroded secondary austenite regions appear in black and the isolated sigma precipitates in white. The only difference is that the amount of corroded area is larger for $10000 \mathrm{~min}$ of ageing. Large primary austenite grains remain in white as usual. To distinguish sigma and primary austenite phases in color, the samples were electrolytically etched with $\mathrm{NaOH}$ reagent. The sigma phase is colored reddish brown and distinguished from the primary austenite which was not affected from the etchant (Figures 9(b) and 10(b)).

When the DLEPR and acid test samples (Figure 5) are compared, they show similar behavior because the same areas were affected in both cases. In other words the attacks have concentrated at sensitized areas. The appearance of the localized attack after immersion test shows large number of black points clearly. This shows that local corrosion is initiated in the secondary austenite phase as what happened in the DLEPR test samples. Once a pit is formed, it rapidly propagates within the initial ferrite region. After a long time of exposure, the corroded area extended and covered a large area including many sigma and austenite phases. As a result, large cavities were developed. This type of corrosion is known as localized corrosion.

As mentioned before, Arikan and Doruk [27] and Arikan et al. [28] presented a study dealing with DLEPR and standard weight loss acid tests for the same type of duplex stainless steel annealed at $1050^{\circ} \mathrm{C}$ for 1 hour and aged at $650^{\circ} \mathrm{C}$ and $725^{\circ} \mathrm{C}$ for the same periods of time. The results are compared in the following paragraphs.

Comparison of the results of micrographs, X-ray, and digital image analysis obtained from samples aged at $650^{\circ}$, $725^{\circ}$, and $800^{\circ} \mathrm{C}$, indicates that the minimum time where sigma was first observed is less than $100 \mathrm{~min}$ at $800^{\circ} \mathrm{C}$, less than $316 \mathrm{~min}$ at $725^{\circ} \mathrm{C}$, and longer as $1000 \mathrm{~min}$ at $650^{\circ} \mathrm{C}$. Both DLEPR and acid tests expose continuous chromium depleted zones leading to intergranular corrosion at $\alpha / \gamma$ phase boundaries and local corrosion around sigma phases precipitated inside the ferrite region.

Samples exhibit nearly the same corrosion rates such as $2.42,2.37$, and 2.06 mdd for 3162,316 , and 100 min of ageing at 650,725 , and $800^{\circ} \mathrm{C}$, respectively, and then increases rapidly with ageing time.

A similar trend for DOS values was observed, but since ferrite decomposition occurs faster at $800^{\circ} \mathrm{C}$, accordingly, sensitization begins in shorter time of ageing than that 725 and $650^{\circ} \mathrm{C}$. This indicates that the DLEPR test provides reasonable results proportional to $\sigma$-phase content.

For ageing at $650^{\circ} \mathrm{C}$ and $725^{\circ} \mathrm{C}$, the sensitization and corrosion rate depend strongly on the extent of chromium and molybdenum depletion. But in the case of $800^{\circ} \mathrm{C}$, both the sensitization and corrosion rate are lower due to the replenishment of the secondary austenite by chromium diffusion from the chromium rich ferrite phase and from the interior of the austenite. As a result, the sensitization and corrosion rate depend strongly on the extent of replenishment of the secondary austenite. Accordingly, this causes a decrease in DOS and hence a decrease in susceptibility to intercrystalline corrosion.

Only the solution annealed samples and the samples aged at $650^{\circ} \mathrm{C}$ for 100 and $316 \mathrm{~min}$ and at $725^{\circ} \mathrm{C}$ for only $100 \mathrm{~min}$ are unsensitized. At higher ageing temperature of $800^{\circ} \mathrm{C}$, the samples are moderately sensitized even for the ageing time less than $100 \mathrm{~min}$. The corresponding DOS value $(1.999 \%)$ and the corrosion rate $(2.06 \mathrm{mdd})$ are indicative of less sensitization.

Prolonged ageing between 1000 and $31622 \mathrm{~min}$ at $800^{\circ} \mathrm{C}$ causes a decrease in DOS (31-61\%) and hence a decrease in corrosion rate in contrary to $725^{\circ} \mathrm{C}$. This may be due to redistribution of chromium in the chromium depleted zones [33] which is indicative of the replenishment of the secondary austenite by chromium diffusion from the chromium rich ferrite phase and from the interior of the austenite.

3.7. Analysis of Polarization Curves in Reverse Scanning. At the beginning of the reverse scanning, the anodic current density decreases and the anodic curve moves to the left (Figure 8). This is an indication of thickening of the oxide film. On decreasing the potential, the anodic current density 


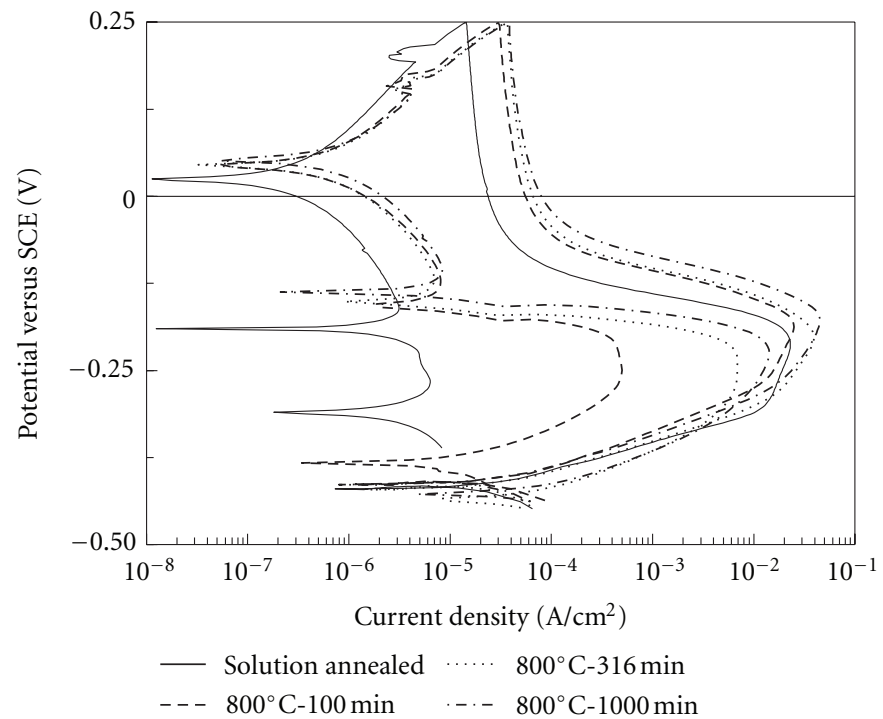

(a)

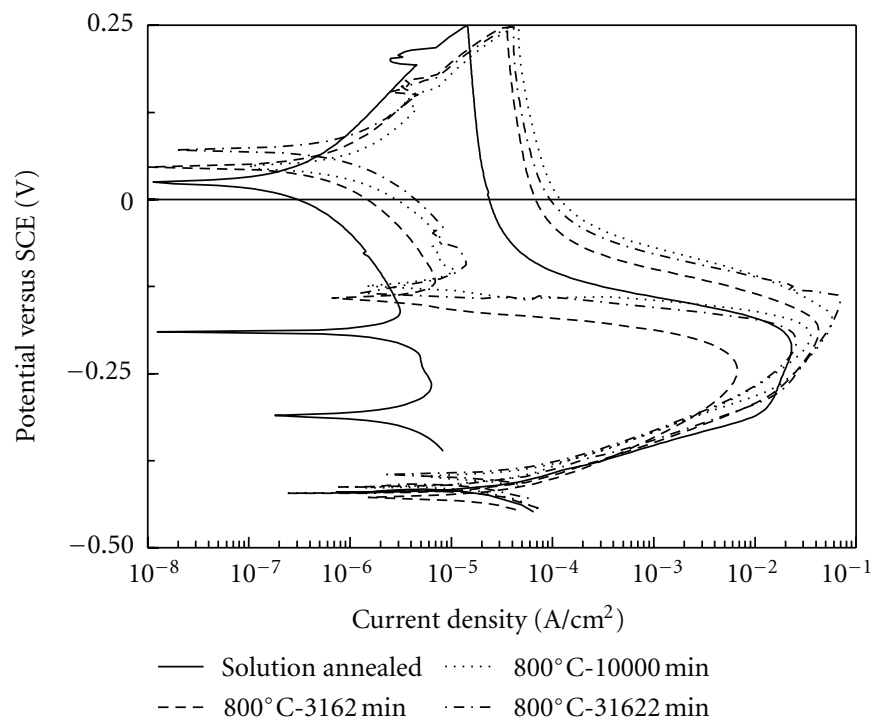

(b)

FiguRE 8: DLEPR curves plotted for DSS after solution and sensitization heat treatments at $800^{\circ} \mathrm{C}$ between 100 and 31622 min (scan rate: $15 \mathrm{~V} / \mathrm{hr})$.

is reduced nearly to zero. This is due to the slowing of the anodic dissolution kinetics caused by thickening of the passive film. The sample has thus continued to passivate from $E_{\text {pass }}$ through $E_{\text {rev }}$, back to potential $E_{3}$. Further reducing the potential, the direction of the current density has changed between $E_{3}$ and $E_{4}$ as shown in Figure 11. It shows a loop consisting of cathodic current [36]. The origin of the cathodic current can be attributed to the fact that at potentials between $E_{3}$ and $E_{4}$, the rate of the cathodic reaction is greater than the anodic current density and hence the net current is cathodic over the potential range, $\Delta E=\left(E_{3}-E_{4}\right)$ (Table 6). If the potential is further reduced on the reverse scan, the direction of the current density changes back and an anodic reactivation loop is generated. This indicates that the oxide has dissolved and metal dissolution reaction has occurred. The development of the reactivation peak current density $\left(I_{r}\right)$ can be attributed to metal dissolution. The lowered reactivation peak current density $I_{r}$ (on the reverse scan) is due to incomplete reactivation of the metal surface.

If no cathodic loop was generated on the reverse scan, the anodic reactivation would begin at a higher potential and would likely reach a high value of $I_{r}$ in a short time, and thus the metal dissolution would take place.

The same cathodic loop behavior is observed on the reverse scans of polarization curves obtained from the solution annealed and aged samples by DLEPR test (Table 6).

The potential ranges $(\Delta E)$ of samples aged at $800^{\circ} \mathrm{C}$ from 100 to $31622 \mathrm{~min}$, where the cathodic loops are obtained, are different from that of the solution annealed sample. In general, their reactivation curves look like that of the solution 


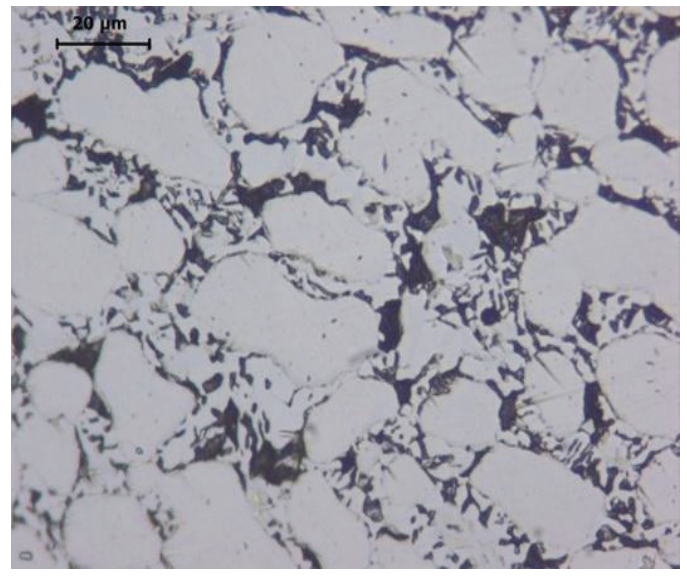

(a)

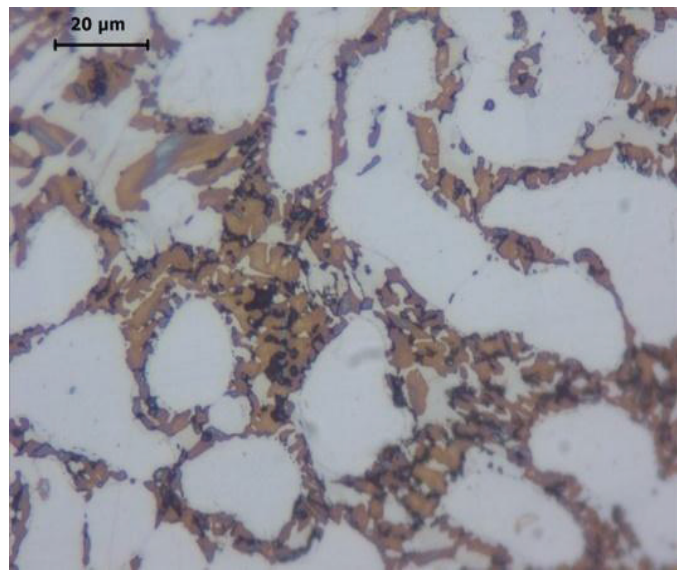

(b)

FIGURE 9: Optical micrographs after DLEPR test for sample aged at $800^{\circ} \mathrm{C}$ for $1000 \mathrm{~min}$. (a) After slightly polished (large austenite in white, attacked regions in black, sigma: small white regions). (b) Electrolytically etched with $\mathrm{NaOH}$ (austenite in white, sigma in brown, attacked regions in black).

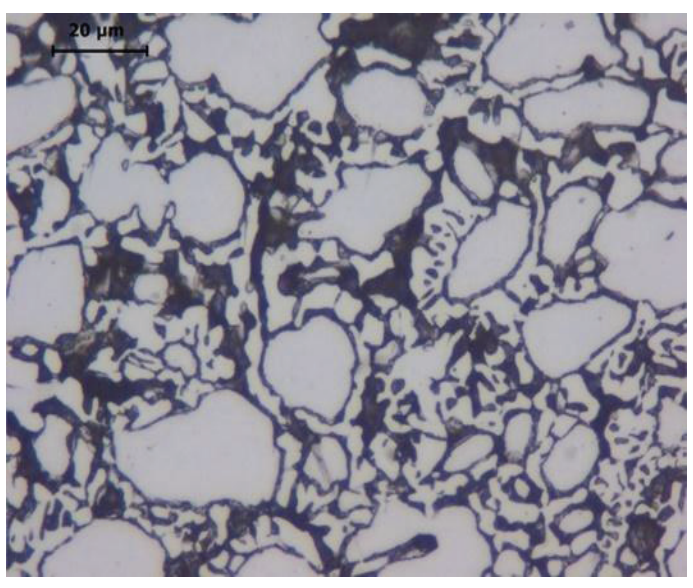

(a)

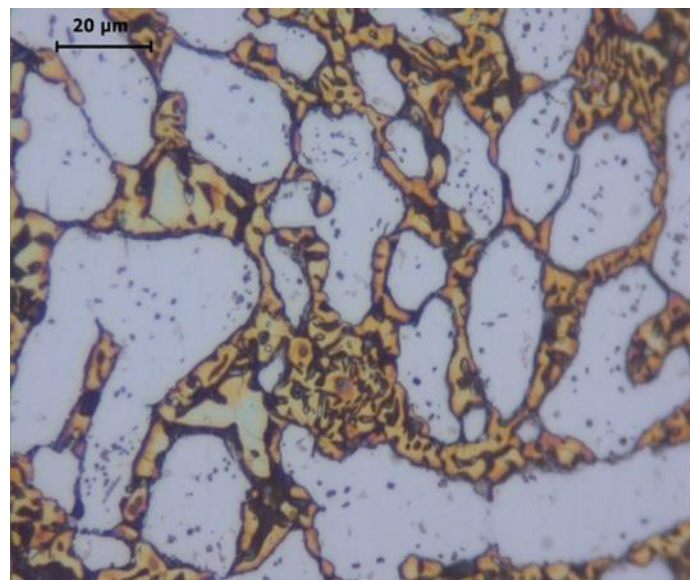

(b)

FIGURe 10: Optical micrographs after DLEPR test for sample aged at $800^{\circ} \mathrm{C}$ for $10000 \mathrm{~min}$. (a) After slightly polished (large austenite in white, attacked regions in black, sigma: small white regions). (b) Electrolytically etched with $\mathrm{NaOH}$ (austenite in white, sigma in brown, attacked regions in black).

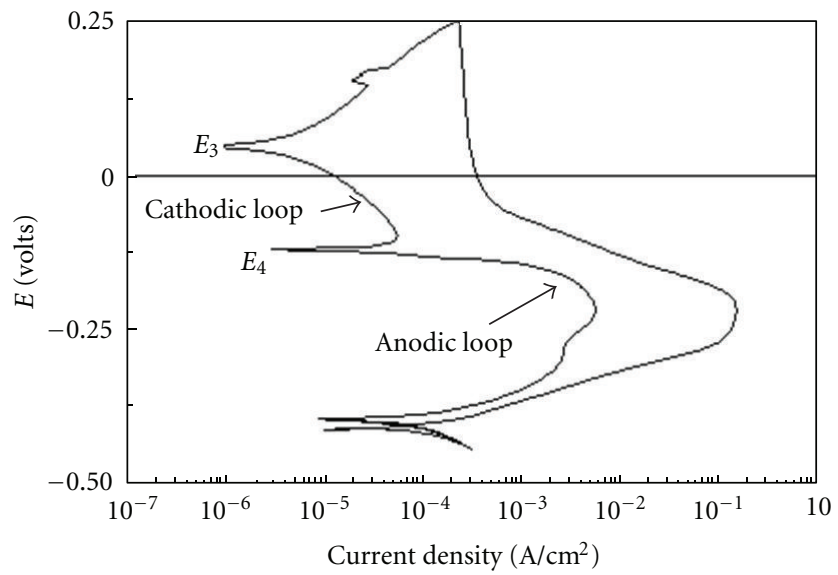

FIGURE 11: Shematic representation of the cathodic and anodic loops on the reverse scan of a polarization curve. 
TABLE 6: DLEPR test results on the reverse scans of polarization curves.

\begin{tabular}{lcccccc}
\hline $\begin{array}{l}\text { Temperature } \\
\left({ }^{\circ} \mathrm{C}\right)\end{array}$ & $\begin{array}{c}\text { Time } \\
(\mathrm{min})\end{array}$ & $\begin{array}{c}E_{3} \\
(\text { volt })\end{array}$ & $\begin{array}{c}E_{4} \\
(\text { volt })\end{array}$ & $\begin{array}{c}\Delta E=\left(E_{3}-E_{4}\right) \\
(\text { volt })\end{array}$ & $\begin{array}{c}I_{r} \\
\left(\mathrm{~mA} / \mathrm{cm}^{2}\right)\end{array}$ & $\begin{array}{c}\text { DOS } \\
\left(I_{r} / I_{a} \times 100\right)\end{array}$ \\
\hline $\begin{array}{l}\text { Solution annealed at } \\
1050^{\circ} \mathrm{C}, 1 \mathrm{hr}\end{array}$ & & 0.02521 & -0.190090 & 0.215300 & 0.0063918 & 0.027634 \\
\hline & 100 & 0.045932 & -0.15449 & 0.200422 & 0.4984463 & 1.999934 \\
& 316 & 0.045098 & -0.15130 & 0.196398 & 6.9135766 & 17.617832 \\
Solution annealed at & 1000 & 0.050937 & -0.13741 & 0.188347 & 14.1895596 & 31.677025 \\
$1050^{\circ} \mathrm{C}, 1 \mathrm{hr}$, then aged at & 3162 & 0.046346 & -0.14173 & 0.188076 & 6.68075480 & 15.680025 \\
$800^{\circ} \mathrm{C}$ & 10000 & 0.048046 & -0.12440 & 0.172446 & 35.3551309 & 61.015094 \\
& 31622 & 0.070888 & -0.13465 & 0.205538 & 25.5835940 & 36.827603 \\
\hline
\end{tabular}

annealed sample. A similar cathodic loop behavior has been observed for all cases but the anodic loops do not resemble that of the solution annealed sample. This indicates that the precipitates developed in the microstructure influence the polarization behavior.

For all cases except for $31622 \mathrm{~min}$ the potential ranges $(\Delta E)$ for the cathodic loops change from 0.200 to 0.172 volt and are less than that of the solution annealed sample. However, the formation of the cathodic loop delays the occurrence of the anodic reactivation current loop even for a short time. Then, the direction of the current density changes back quickly and the anodic reactivation current density begins to be generated at a potential of $E_{4}=-0.15449 \mathrm{~V}$ for ageing $100 \mathrm{~min}$. It then reaches the peak value of $I_{r}=$ $1.4984463 \mathrm{~A} / \mathrm{cm}^{2}$ with the DOS value of $1.9999 \%$ for ageing $100 \mathrm{~min}$.

For the sample aged for $316 \mathrm{~min}$, the potential range $(\Delta E)$ for the cathodic loop is $0.196398 \mathrm{~V}$. This is lower than the value measured for the solution annealed one. The dissolution of oxide begins at a high potential such as $E_{4}=-0.15130 \mathrm{~V}$. After a short delay, the reactivation current density reaches $I_{r}=6.91357 \mathrm{~A} / \mathrm{cm}^{2}$. The DOS value is $17.617 \%$.

For the sample aged for $1000 \mathrm{~min}$, the potential range $(\Delta E)$ for the cathodic loop is $0.188347 \mathrm{~V}$. This is lower than the value measured for $316 \mathrm{~min}$ of ageing. The $E_{4}$ (= $-0.13741 \mathrm{~V})$ and $E_{3}(=0.050937 \mathrm{~V})$ have been found higher with increasing ageing time. The reactivation peak current density $\left(I_{r}\right)$ has reached to $14.189 \mathrm{~mA} / \mathrm{cm}^{2}$ corresponding to a high DOS value (31.677\%).

For the sample aged for $3162 \mathrm{~min}$, the range of the potential for the cathodic loop is $0.188076 \mathrm{~V}$. This is more or less the same as the value obtained for $1000 \mathrm{~min}$ of ageing. But the $E_{4}(=-0.14173 \mathrm{~V})$ is higher and $E_{3}(=$ $0.046346 \mathrm{~V}$ ) is lower than the value obtained for $1000 \mathrm{~min}$ of ageing. The reactivation peak current density $\left(I_{r}\right)$ has decreased to $6.6807 \mathrm{~mA} / \mathrm{cm}^{2}$ corresponding to a low DOS value $(15.680 \%)$.

For ageing time of 10000 and 31622 min, cathodic loops on the reverse scan are obtained within a potential range of 0.172446 and $0.205538 \mathrm{~V}$, respectively. And then the anodic reactivation loops suddenly begin to be generated at higher potentials of $E_{4}$ such as -0.12440 and $-0.13465 \mathrm{~V}$, respectively. The reactivation peak current densities $\left(I_{r}\right)$ have reached to 35.355 and $25.583 \mathrm{~mA} / \mathrm{cm}^{2}$ and the corresponding DOS values are 61.015 and $36.827 \%$, respectively. As seen from Table 6, the $E_{3}$ and $E_{4}$ have changed disorderly with increasing ageing time.

For all cases the cathodic loops delay the occurrence of the anodic reactivation loops. The anodic reactivation peak current densities increased constantly until the peak current densities $\left(I_{r}\right)$ were reached but they were also found lower than that obtained at $725^{\circ} \mathrm{C}$ for all ageing times. Since the $I_{r}$ values depend closely on the dissolution reaction of the phases in the metal, during the reactivation sweep only the chromium depleted areas contribute to the passiveactive transition. But at $800^{\circ} \mathrm{C}$ longer ageing from 1000 to 31622 min causes limited replenishment of the chromium depleted zones. Consequently, this resulted in lower $I_{r}$ and hence lower DOS values.

The limited replenishment of the chromium depleted zones also caused larger potential range for cathodic loops and the $E_{4}$ values are also found lower than those obtained at $725^{\circ} \mathrm{C}$. This is why the occurrence of the anodic reactivation loops was delayed more.

A similar behavior has been observed for the passive current densities $\left(I_{\text {pass }}\right)$. The chromium depletion or dissolution of secondary austenite phase $\left(\gamma_{2}\right)$ causes the passive current densities to shift to higher current densities as compared to that obtained from the solution annealed sample (Figure 8, Table 5). But the $I_{\text {pass }}$ values are lower than the values obtained at $725^{\circ} \mathrm{C}$ because of the limited replenishment of the chromium depleted zone at $800^{\circ} \mathrm{C}$.

\section{Conclusion}

First, the effect of isothermal treatment at $800^{\circ} \mathrm{C}$ on the microstructures and consequent corrosion behavior of a duplex stainless steel UNS S31803 was investigated. Then the results were compared with the previous results obtained from samples aged at 650 and $725^{\circ} \mathrm{C}[27,28]$. The important findings are summarized as follows.

(a) The solution annealed sample is unsensitized condition. The structure is free of precipitations, and consequently it presented a very small reactivation current. When aged at $800^{\circ} \mathrm{C}$ the samples were 
sensitized even for ageing less than $100 \mathrm{~min}$. The corresponding DOS value (1.999\%) and the corrosion rate $(2.06 \mathrm{mdd})$ are indicative of sensitization.

(b) Comparison of the results of micrographs, X-ray, and digital image analysis obtained from samples aged at $800^{\circ}, 725^{\circ}$, and $650^{\circ} \mathrm{C}$ indicate that the minimum time where sigma was first observed was less than $100 \mathrm{~min}$ at $800^{\circ} \mathrm{C}$, less than $316 \mathrm{~min}$ at $725^{\circ} \mathrm{C}$, and as long as $1000 \mathrm{~min}$ at $650^{\circ} \mathrm{C}$. However, the degree of sensitization increased rapidly with increasing ageing time for all the cases. This can be attributed to a higher contribution of chromium and molybdenum depleted areas resulting in the formation of the intermetallic phases.

(c) Prolonged ageing between 1000 and $31622 \mathrm{~min}$ at $800^{\circ} \mathrm{C}$ caused a decrease in DOS (31-61\%) and hence a decrease in corrosion rate in contrary to $725^{\circ} \mathrm{C}$ and $650^{\circ} \mathrm{C}$. A possible explanation of this is that it may be due to redistribution of chromium in the chromium depleted zone [33] which is indicative of the replenishment of the secondary austenite by chromium diffusion from the chromium rich ferrite phase and from the interior of the austenite.

(d) For all cases from the observations of the polarization curves it may be concluded that cathodic loops do not affect metal dissolution. They merely delay the occurrence of anodic loops for a short time in a small potential range. These potential ranges $(\Delta E)$ measured over the cathodic loops depend on the protective film thickness, ageing temperature, time, and microstructural changes in the material. Actually, during the anodic sweep, the entire surface is active and contributes to peak current. But, during the reactivation sweep, only the sensitized areas contribute to the passive-active transition. Thus, unsensitized specimen show a small $I_{r}$ and therefore a small $\left(I_{r} / I_{a}\right)$ ratio, while in heavily sensitized specimens, $I_{r}$ approaches $I_{a}$, giving a high $\left(I_{r} / I_{a}\right)$ ratio. Oxide dissolves first and then metal dissolution takes place.

The peak reactivation current density $\left(I_{r}\right)$ depends closely on the dissolution reaction in the metal. But higher temperature treatment such as $800^{\circ} \mathrm{C}$ leads to limited replenishment of the chromium depleted regions (secondary austenite) and hence reduced the amount of sensitized areas. This allowed less dissolution of the secondary austenite phase resulting in lower $I_{r}$ and hence lower DOS values. This means that the sensitization and corrosion rate depend strongly on the extent of replenishment of the secondary austenite.

\section{References}

[1] A. Wensley and C. Reid, "Duplex stainless steels in the pulp and paper industry," in Proceedings of the Duplex Stainless Steels, J. Charles and S. Bernhardsson, Eds., vol. 1 of Les Editions de Physique, pp. 1099-1110, 1992.

[2] J. Husbands and P. K. Whitkraft, "CORROSION/91," Paper 171, NACE, Houston, Tex, USA, 1991.
[3] D. J. A. Fruytier, in DuplexStainless Steels '91, J. Charles and S. Bernhardsson, Eds., Les Editions de Physique, p. 499, 1992.

[4] P. Jolly, Bulletin du Cercle d'Etudes des Metaux, vol. XII-5, no. 5, p. 317, 1973.

[5] D. Y. Kobayashi and S. Wolynec, "Evaluation of the low corrosion resistant phase formed during the sigma phase precipitation in duplex stainless steels," Materials Research, vol. 2, no. 4, p. 239, 1999.

[6] J. S. Kim and H. S. Kwon, "Effects of tungsten on corrosion and kinetics of sigma phase formation of $25 \%$ chromium duplex stainless steels," Corrosion, vol. 55, no. 5, pp. 512-521, 1999.

[7] G. M. Gordon, "Physical Metallurgy of Fe-Cr-Ni Alloys," in Stress Corrosion Cracking and Hydrogen Embrittlement Iron Base Alloys, R. W. Staehle, Ed., pp. 893-945, NACE, Houston, Tex, USA, 1977.

[8] E. O. Hall and S. H. Algie, “The Sigma phase," Metallurgical Reviews, vol. 11, pp. 61-88, 1966.

[9] T. A. Debold, "Duplex stainless steel-microstructure and properties," Journal of metals, vol. 41, no. 3, pp. 12-15, 1989.

[10] S. D. Brandi and A. F. Padilha, in Proceedings of 2nd Brazilian Seminars on Stainless Steels-(INOX '90), pp. 135-152, ABM, Sao Paulo, Brazil, 1990.

[11] Y. Maehara, M. Koike, N. Jujiro, and T. Kunitake, Transactions of the Iron and Steel Institute of Japan, vol. 23, no. 3, p. 669, 1983.

[12] P. Jolly and J. Hochmann, "Structural changes in austeniticferritic stainless steel on holding between 600 and $1150 \mathrm{C}$," Memoires et Etudes Scientifiques de la Revue de Metallurgie, vol. 70, no. 2, pp. 117-124, 1973.

[13] J. M. Vitek and S. A. David, "Sigma phase transformation in austenitic stainless steels," Welding Journal, vol. 65, no. 4, p. 106, 1986.

[14] "Duplex stainless steel: a tale of two phases," in Proceedings of the Duplex Stainless Steels Conference, H. D. Solomon, T. M. Devine, and R. A. Lula, Eds., p. 693, ASM, Metals Park, Ohio, USA, 1984.

[15] C. H. Shek, K. W. Wong, and J. K. Lai, "Review of temperature indicators and the use of duplex stainless steels for life assessment," Materials Science and Engineering $R$, vol. 19, no. 5-6, pp. 153-200, 1997.

[16] M. E. Wilms, V. J. Gadgil, J. M. Krougman, and B. H. Kolster, "Effect of $\sigma$-phase precipitation at $800^{\circ} \mathrm{C}$ on the mechanical properties of a high alloyed duplex stainless steel," Materials at High Temperatures, vol. 9, no. 3, pp. 160-166, 1991.

[17] T. H. Chen and J. R. Yang, Materials Science and Engineering A, vol. 11, p. 28, 2001.

[18] N. Lopez, M. Cid, and M. Puiggali, "Influence of $\sigma$-phase on mechanical properties and corrosion resistance of duplex stainless steels," Corrosion Science, vol. 41, no. 8, pp. 16151631, 1999.

[19] R. Francis, "Discussion on: influence of Sigma phase on general and pitting corrosion resistance of 2205 duplex stainless steel by J H Potgieter," British Corrosion Journal, vol. 27, no. 4, pp. 319-320, 1992.

[20] F. Egan, Stainless Steel World, vol. 9, no. 10, p. 61, 1997.

[21] R. N. Gunn, The Twi Journal, vol. 7, no. 1, pp. 5-45, 1998.

[22] J. E. Truman and K. R. Pirt, in Duplex Stainless Steel, R. A. Lula, Ed., pp. 113-142, ASM, Metals Park, Ohio, USA, 1983.

[23] K. N. Adhe, V. Kain, K. Madangopal, and H. S. Gadiyar, "Influence of sigma-phase formation on the localized corrosion behavior of a duplex stainless steel," Journal of Materials Engineering and Performance, vol. 5, no. 4, pp. 500-506, 1996.

[24] M. E. Wilms, V. J. Gadgil, J. M. Krougman, and F. P. Ijsseling, "The effect of $\sigma$-phase precipitation at $800^{\circ} \mathrm{C}$ on the corrosion 
resistance in sea-water of a high alloyed duplex stainless steel," Corrosion Science, vol. 36, no. 5, pp. 871-881, 1994.

[25] ASTM A262-02: Standard Practices for Detecting Susceptibility to Intergranular Attack in Austenitic Stainless Steels.

[26] ASTM G108-94: Standard Test Method for Electrochemical Reactivation (EPR) for Detecting Sensitization of AISI Type 304 and 304L Stainless Steels.

[27] M. E. Arikan and M. Doruk, "Determination of susceptibility to intergranular corrosion of UNS 31803 type duplex stainless steel by electrochemical reactivation method," Turkish Journal of Engineering and Environmental Sciences, vol. 32, no. 6, pp. 323-335, 2008.

[28] M. E. Arikan, R. Arikan, and M. Doruk, "Determination of susceptibility to intergranular corrosion of UNS 31803 type duplex stainless steel by electrochemical reactivation method," International Journal of Corrosion, vol. 2012, Article ID 651829, 10 pages, 2012.

[29] ASTM A923-03: Standard Test Methods for Detecting Detrimental Intermetallic Phase In Duplex Austenitic / Ferritic Stainless Steels.

[30] A. P. Majidi and M. A. Streicher, "Potentiodynamic reactivation method for detecting sensitization in alsl 304 and 304L stainless steels," Corrosion, vol. 40, no. 8, pp. 393-408, 1984.

[31] A. P. Majidi and M. A. Streicher, Paper presented at NACE, CORROSION/84, no. 261, 1984.

[32] "Duplex stainless steel: a tale of two phases," in Proceedings of the Duplex Stainless Steels, H. D. Solomon, T. M. Devine, and R. A. Lula, Eds., p. 693, Metals Park, Ohio, USA, 1984.

[33] E. L. Hall and C. L. Briant, "Chromium depletion in the vicinity of carbides in sensitized austenitic stainless steels," Metallurgical and Materials Transactions A, vol. 15, no. 5, pp. 793-811, 1984.

[34] R. N. Wright, in Toughness of Ferritic Stainless Steels, R. A. Rula, Ed., vol. 706, p. 2, ASTM-Special Technical Publication, West Conshohocken, Pa, USA, 1979.

[35] C. J. Park and H. S. Kwon, "Effects of aging at $475^{\circ} \mathrm{C}$ on corrosion properties of tungsten-containing duplex stainless steels," Corrosion Science, vol. 44, no. 12, pp. 2817-2830, 2002.

[36] A. Legat and V. Dolecek, "Chaotic analysis of electrochemical noise measured on stainless steel," Journal of the Electrochemical Society, vol. 142, no. 6, pp. 1851-1858, 1995. 

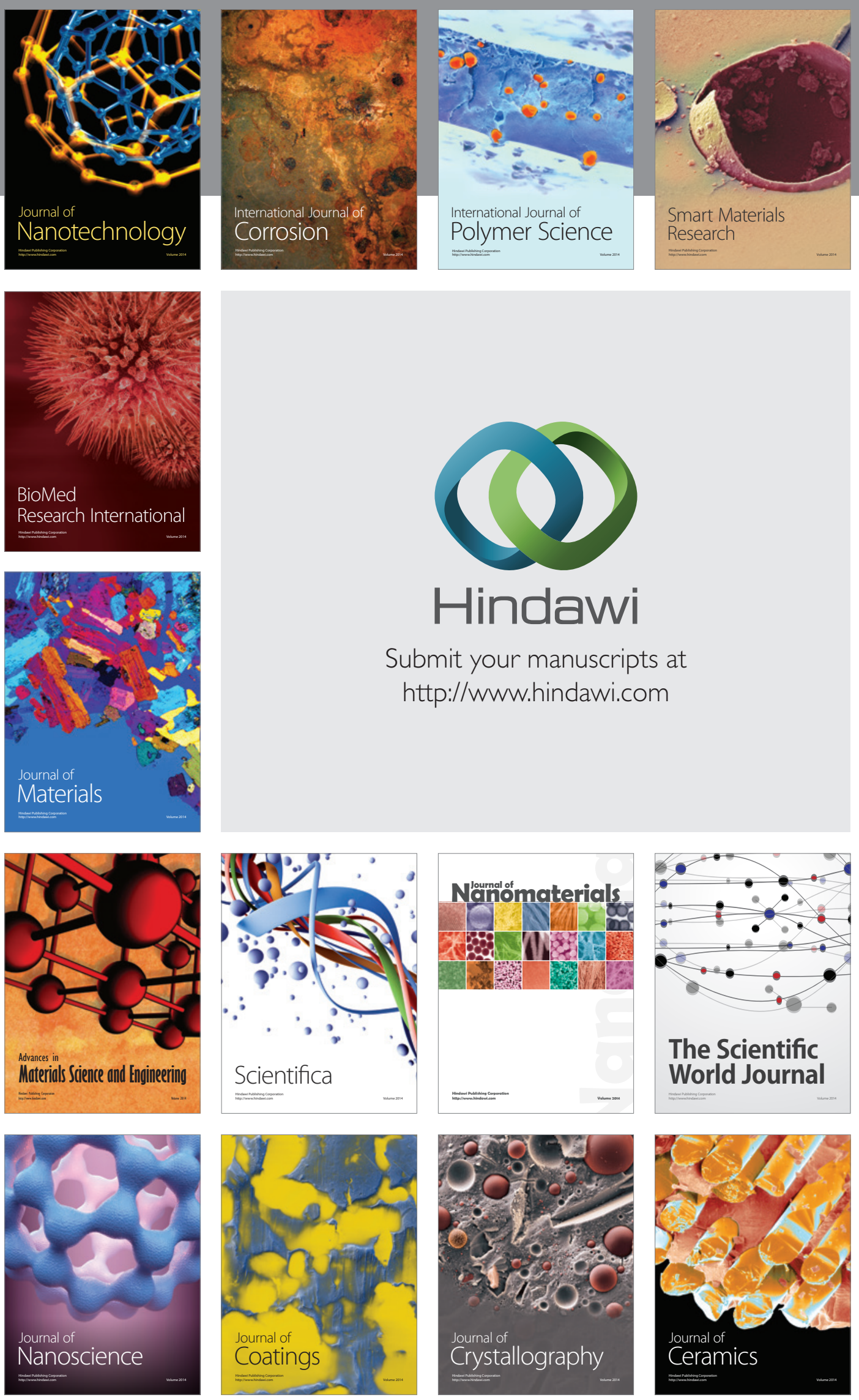

The Scientific World Journal

Submit your manuscripts at

http://www.hindawi.com

\section{World Journal}

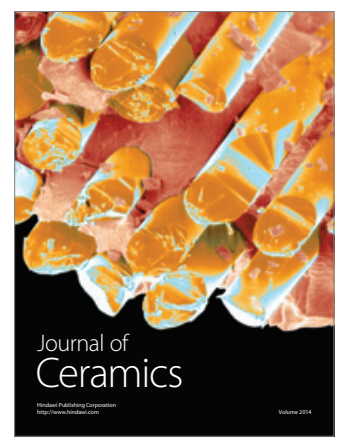

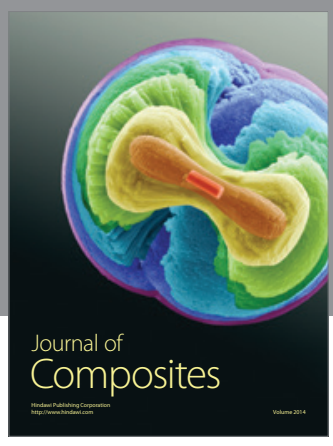
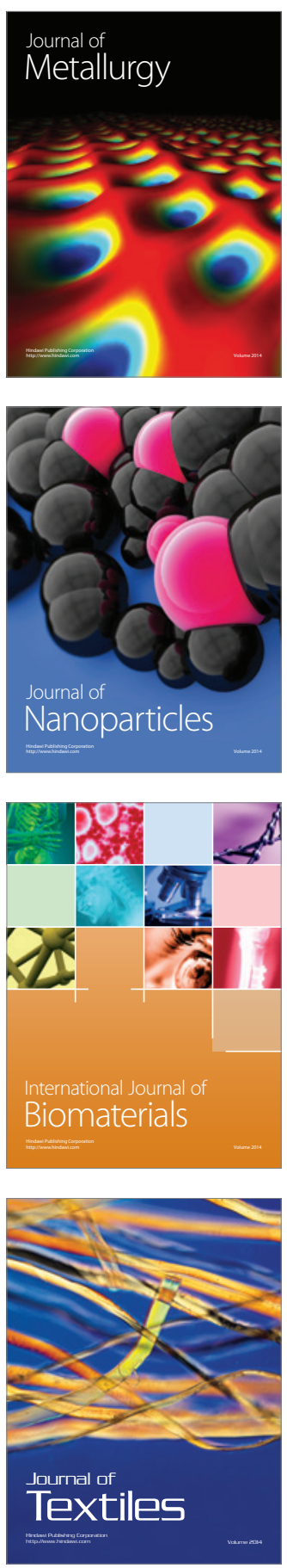